\title{
The Impact of Media and Legal on Earnings Management: Substitution or Complement?
}

\author{
Ling-wen Kong \\ Faculty of Management and Economics, Dalian University of Technology \\ NO.2 Linggong Road, Ganjingzi District, Dalian 116024, China
}

\begin{abstract}
This article takes the listed company earnings management as the entry point,and studied the governance effect of media monitor and legal environment on the earnings management of listed companies. The study found that: first, the media monitor can effective constraint of the listed company earnings management behavior, namely with the increase of the degree of media monitor, the degree of the accrual-based earnings management and real earnings management of listed companies will decrease; Second, media monitor will have an important impact on the earnings management strategy of listed companies, namely, under the pressure of media supervision, listed companies tend to use more real earnings management, and use fewer accrual-based earnings management; Third, the media monitor and legal environment in earnings management governance exist significant substitution effect. Media monitor can fill the issue of the failure of earnings management supervision due to weak legal environment. Keywords: Earnings Management, Media Monitor, Legal Environment
\end{abstract}

DOI: $10.7176 /$ RJFA/10-4-13

\section{Introduction}

The traditional law and finance theory holds that a sound legal system can effectively promote enterprise value growth as well as reducing earnings management behavior of the enterprises. In reality, however, most of the countries undergoing economic transition are faced with a problem of weak legal environment. New China was founded more than sixty years ago, and after hard explorations and bold attemptson the rule of law, the country has made tremendous achievements, and gradually formed a legal system in line with the socialist market economy. But still, there is a noticeable imbalance on the rule of law environment in China where the eastern coastal areas have a better legal environment than central and western regions.In some regions which are faced with weak or even legal environment failure, the market will turn to available alternative protection mechanisms to constrain earnings management of listed companies, which calls for a serious consideration by practitioners and theoretical circles.In recent years, media has played an important supervisory role in the financial fraud cases involving listed companies, making the majority of investors see the media's power. So, what role will the media play in the governance of earnings management of listed companies? What mutual-impact will media attention and legal environment have on earnings management? These issues have yet to be fully explored.

In view of this, this study empirically tests the impact mechanism of media attention on earnings management of listed companies by using data of Chinese companies listed in Shanghai and Shenzhen stock exchanges. The study also attempts to find the evidence on the listed companies' earnings management policy change as well as exploring the governance impact of legal environment and media attention on earnings management. This paper contributes to the literature in the following three ways: first, from the media attention perspective, this paper investigates media's governance impact on earnings management of listed companies, where we find that media can effectively constrain earnings management of listed companies. The study expands on the scope of the tradition researches on earnings management that adds theoretical value to the study. Furthermore, the study clarifies the role of media attention on the listed companies' earnings management policy shift, revealing that listed companies will be forced to change earnings management strategy, in which they will prefer to engage more on real earnings management. This enriches empirical evidence on the earnings management problem in a capital market of a transitional economy. In addition, third, the study reveals that media attention and legal environment have a significant substitution effect on the earnings management governance. This will help to find other earnings management governance factors apart from law.

\section{Related literature review and hypotheses development}

\subsection{Institutional background}

Developed western countries are characterized by a relatively high level of market-oriented media industry where governments rarely use ownershipcontrol to influence the daily operations and management, set less strict industry access regulations, as well as introducing anti-monopoly laws to encourage free competition among media networks. Also constitution and related press laws give media supervisory power towards the government, businesses and individuals, which allows media to play a "social justice tool" role. In China, the media industry has a strong ideological attributes. The government has set out various measures that strictly control establishment and conduct of media in the country. The implementation of strict control is to ensure and maintain political and 
social stability, as well as improving efficiency to media access. Those and several other aspects have an important practical significance. However, the strict controlling nature ofthe existing media supervision regulations have brought a negative effect on the media's growth. The rise of global media industry deregulation wave in the 80's provided China's media industry with a great opportunity. State's support to the private investment in the media industry encourages local media to adopt market-oriented approach to operations management, which helps to create a favorable external environment for the development of China's media industry.Thus, with the ongoing deepening of market-oriented reforms, China's media has seen a rapid developing, for instance, "China Media Industry Development Report (2014)" reveals that media industry's total output reached \$130.2 Billion in 2013, an increase of $16.2 \%$. The role of media has become increasingly important in the social spheres with the growth of media industry, particularly in the exposure and legal proceedings of a series of major financial fraud cases involving, for instance, "Yingguangxia", "China Lantian", "Smith Barney", "Health America Pharmaceuticals", "Zoomlion", just to mention a few. Media has played a vivid corporate governance role, as a result media attention has gradually received public recognition.

\subsection{Related literature review}

Since the publication of thecelebrated Zingales(2000)'review article, academicians have attached a great importance on the media's role in financial circles, which has opened the door for further researches on the theory of media governance.Miller(2006) using American firms found guilty of accounting fraud reveals that media can be used as an effective tool to restrain financial manipulation, while Dyck et al. (2008) suggest that western media's exposure of Russian companies' financial violations help to force the companies to correct their misconducts. These evidences remind us that there is a need to attach a greater importance to the role of media attention as an alternative governance mechanism though, to our best knowledge, there exists a few studies which explore the governance impact of media attention on earnings management behavior of listed companies. However, some studies question the role of media in corporate governance and suggest the assertion of media reporting biases, that is, biased media theory. Gentzkow and Shapiro (2006), and Core et al.(2008) suggest that, to ensure maximum impact, media have a tendency of pursuing for entertainment or sensionalism. Reuter and Zitzewitz(2006) finds the evidence of media reports deviation so as to cater to the advertisers. $83.8 \%$ of the fund companies were selected by Money Magazine among top 100 fund companies after spending more than a million US dollars on advertisement to the magazine. In addition, Ellman and Germano(2009) point that with the increase in the advertising revenues, media companies will avoid news coverage with negative impact to the advertisers. Gurun and Butler(2012) confirm that view. They find that due to the excessive dependency on the advertising revenues, local US media tend to positively report local companies. The governance role of media is often subjected to problems such as press freedom, media capture, media rents. These problems are closely linked to the legal environment. And, as an external governance mechanism, legal environment can play an important governance role to the earnings management of listed companies. Existing literature have not yet succeeded in addressing the joint-impact of media attention and legal environment on the listed companies' earnings management problem. It might be substitution effect or complimentary effect. Thus, from the unique China's institutional background, how will the two external governance environments interact needs to be further investigated.

\subsection{Research hypotheses}

On the one hand, media have a strong incentive to monitor the earnings management behavior of listed companies: First, from cost-benefit consideration. The media's main concern is access costs and expenditures arising from press releases, which include staff travel and salaries, with printing costs and website maintenance expenses being relatively low. But, the discovery of company's financial frauds and other irregularities may enhance the media's reputation and visibility which may increase revenues from advertisement and subscription fees as well as boosting online traffic, etc. Thus, it can be seen that, the marginal benefit of media's focus on corporate earnings management behavior outweighs its marginal cost, hence media have a strong incentive to monitor earnings management behavior of enterprises. Second, from demand-supply consideration. As the provider of news in the media market, the media would try to attract public attention by reporting hot topics. Reporting news related to corporate earnings management can improve media's social reputation and public image which can create more business value to the media.

On the other hand, media attention can use the following four methods to effectively impact listed companies' earnings management behavior: first intervention by regulatory authorities. Since media reports provide information to regulatory authorities concerning listed companies' earnings manipulation and information asymmetry behaviors, this may cause widespread concern in the community which can force regulatory authorities to improve inspection, thereby increasing the chance of regulatory authorities to discover earnings manipulation activities of listed companies. Meanwhile, since administrative intervention caused by the media coverage can cause a negative impact to the company, thus listed companies will reduce the level of earnings manipulation. Second, manager's reputation. With respect to incentive pay, top executives of state-owned enterprises (SOEs) are 
more in pursuit of political objectives. Under media attention, executives would not consider the use of earnings manipulation so as notto risk damaging their reputation, future employment opportunities and political career, since good reputation can ensure higher premiums in managerial positions. Third, investors' "voting with their feet." Media use their available resources to act as an important information intermediary to disseminate valuable information to the public. Drake et al.(2014) find that media reporting of listed companies' information can reduce information asymmetry in the market which helps investors understand accounting information and reasonable pricing. On the basis of obtaining a more comprehensive and objective understanding of the listed company, investors can use "voting with their feet" approach to vent their frustration for the company's earnings manipulation discontent. Thus, to avoid seeing company's stock price plummet, management will take measures to reduce earnings manipulation. Fourth, Joe(2003) suggests that media can affect auditor's decisions-making behavior. A media's "bad report" reporting concerning a listed company tends to cause auditors to issue a qualified opinion. When a listed company is surrounded by media coverages and attention, auditors will be more diligent during the auditing process so as to maintain their reputation. At this point, auditor's tolerance to the earnings management behavior of the listed company's financial report will be significantly reduced, hence to avoid getting issued with a qualified audit report, the listed company will reduce earnings manipulation. Therefore, from above, we propose the following hypothesis:

Hypothesis 1: Media attention can effectively constrain earnings management of listed companies. With the enhancement of media attention, accrual-based and real earnings management of listed companies will be reduced. Hypothesis 2: Media attention can affect listed company's earnings management strategy; that is, with the strengthening of media attention, earnings management strategy of a listed company will change from accrualbased to real earnings management.

As a new way of manipulating earnings, real earnings management will damage company's cash flow and its long-term performance, and since earnings management is heavily concealed, this brings a great challenge to the related regulatory authorities. Academic circles have in recent years engaged in a fierce debate concerning earnings management achieving promising results. Existing literature mainly study the incentives for earnings management strategic change from institutional aspects: Cohen et al.(2008) suggests thatthe enactment of Sarbanes-Oxley Act (SOX) has led US listed companies to prefer the use of real earnings management, and they will gradually reduce the use of accrual-based earnings management. Chi et al. (2011) point out that companies facing high risk of lawsuits and strict external audit will increase the use of real earnings management. This is mainly due to the fact that, under the premise of meeting information disclosure requirement, real earnings management acts don't constitute an offence to the related laws and regulations. Zang(2012) also finds that strengthening of accounting supervision will lead to the increase in real earnings management. This study, from media attention perspective, explores the impact mechanism of media attention on earnings management strategies of listed companies. With the improvement of media attention, $t$ is becoming increasingly easier for regulators to identify accrual-based earnings management activities, thus listed companies will have to find better alternative means to achieve the expected earnings target. Considering that real earnings management is based on real economic activities hence more concealed and difficult to spotted by regulators than accrual-based earnings management, so due to the pressure from the media, listed companies will reduce accrual-based earnings management and increase real earnings management activities. Therefore, will propose the following hypothesis:

Legal environment plays a major role in earnings management governance. Houqe et al.(2012), Fung et al. (2013) find the real evidence that legal environment restrains enterprises earnings management. But, similar to other countries under economic transition, China's legal environment is relatively weak, particularly western economically backward regions. When mandatory corrective legal aspects in areas with weak or malfunctioning rule of law fail to suppress earnings management behavior, the market will spontaneously derive alternative corrective mechanisms to protect investors. Media acting as an independent "fourth power" to the legislative, judicial and executive, can effectively restrain enterprise irregularities and solve market failure. Media attention is an important alternative institutional arrangement in emerging capital markets with inefficient legal regimes. But the influence of media attention is weakened in regions with better legal environment as the legal system can fulfill its earnings management supervisory responsibility. Therefore, the supervisory effectiveness of media is more significant in regions with poor legal environment. Media capture the attention of the public and government through reporting earnings management behaviors of listed companies which puts pressure on companies' management. Taking into consideration the cost on reputation and heavy penalties, listed companies will reduce the level of earnings management. Therefore, we propose the following hypothesis:

Hypothesis 3: There exists a substitution effect between media attention and legal environment on earnings management governance. Media attention can effectively reduce weak-legal-environment-induced earnings management. 


\section{Research design}

\section{1 sample selection and data sources}

This study selects using data of Chinese companies listed in Shanghai and Shenzhen stock exchanges for the period 2009-2013 by means of following procedures: First, the samples of ST and *ST companies were rejected. Second, rejecting financial samples. Last, rejecting samples with incomplete Financial and Corporate governance data. We get 6261 observation samples finally. The financial data of listed companies mainly comes from the Wind database, Corporate governance data from the CSMAR database, GDP data from China Statistical Yearbook, legal environment data from"China's marketization index - the 2011 report on the relative process of marketization in all regions" ,Media attention data from CNKI Chinese important newspaper Full-text Database and Baidu news search engine.

\subsection{Variable definitions}

\subsubsection{Explained Variable}

Firstly, Accrual-based Earnings Management

The main method to measuring accrual-based earnings management is cross-sectional modified jones model. Bartov et al.(2000) test and find using modified jones model could measure accrual-based earnings management degree effectively. The specific model is as follows:

$$
N D A_{i t}=\hat{\alpha}_{1} \frac{1}{A_{i \neq-1}}+\hat{\alpha}_{2} \frac{\Delta R E V_{i t}-\Delta R E C_{i t}}{A_{i \neq-1}}+\hat{\alpha}_{3} \frac{P P E_{i t}}{A_{i \neq-1}}
$$

Where, for fiscal year $\mathrm{t}$ and firm $\mathrm{i}$, NDAit represents the impractical accrual-baseds defines as:

$\mathrm{A}_{\mathrm{i}, \mathrm{t}}-1=$ total assets;

$\triangle P E V_{\mathrm{u}}$

$\triangle P E C$

$=$ change in revenues from the preceding year;

PPEit $=$ gross value of property , plant, and equipment;

To obtain coefficient estimates, we run the following cross-sectional regression year by Equation (2).

$$
\frac{T A_{i t}}{A_{i \neq-1}}=\alpha_{1} \frac{1}{A_{i \neq-1}}+\alpha_{2} \frac{\Delta R E V_{i+1}}{A_{i \neq-1}}+\alpha_{3} \frac{P P E_{i+1}}{A_{i \neq-1}}+\varepsilon_{i t}
$$

Where, TAi $=$ EBXIi,t - CFOi,t, EBXI is the earnings before extraordinary items and discontinued operations and $\mathrm{CFO}$ is the operating cash flows (from continuing operations) taken from the statement of cash flows;

Secondly, Real accrual-based management

Real accrual-based management: from sales manipulation, production manipulation and discretionary expenditure, Roychowdury(2006) constructs the most authoritative real accrual-based management model so far. This model is applied by Franz et al.(2014) ,Defond and Zhang(2014),Alhadab et al. (2015) extensively:

$$
\frac{C F O_{i t}}{A_{i \neq-1}}=\beta_{1} \frac{1}{A_{i \neq-1}}+\beta_{2} \frac{S a l e s_{i t}}{A_{i \neq-1}}+\beta_{3} \frac{\Delta S a l e s_{i t}}{A_{i \neq-1}}+\xi_{i t}
$$

In the above equations CFO is operating cash flows in period t; Salesi,t is the sales volume; $\Delta$ Salesi,t represents the change in sales volume from the preceding year; the (REM_CFO) is computed as the difference the actual values and the normal levels predicted from Equations (3)

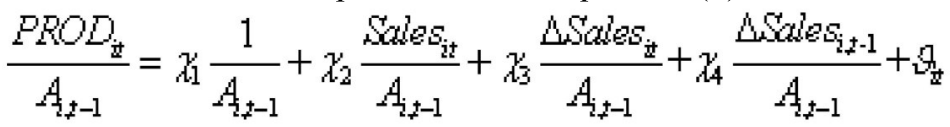

Where, PROD represents the production cost in period t, defined as the sum of COGS (cost of goods sold) and the change in inventories; $\Delta$ Salesi,t-1 represents the change in sales volume in period from the period $t-2$; the (REM PROD) is computed as the difference the actual values and the normal levels predicted from Equations (4).

$$
\frac{D I S E X P}{A_{i \neq t}}=\delta_{1} \frac{1}{A_{i \neq-1}}+\delta_{2} \frac{S a l e s_{i \neq-1}}{A_{i \neq 1}}+\varpi_{i t}
$$

Where, DISEXPi,t represents discretionary expenditure in period $t$, defined as the sum of selling expenses and administration expense; the (REM_DISEXP) is computed as the difference the actual values and the normal levels predicted from Equations (5)

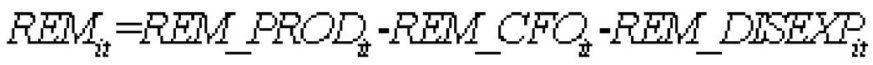


Equation (6) is the real accrual-based management aggregative model, where REM represents the degree of real accrual-based management. It should be remarked that all variables involved in this real accrual-based management model are used Ai,t-1 to deflate.

3.2.2 Explanatory Variables

Media Monitor: The resent media consists mainly print media, network media and personal media, considering that the information appealed by personal media is with lower reliability and collected difficultly, we mainly selected print media and network media as intelligence-collecting object. Using experience from Liang Hongyu et al. for reference, If the number of media reports of a listed company is more, it indicates that the media has more supervision over this company. Firstly, Print Media Monitor(PMM).At first, Data sources. Data is from CNKI Chinese important newspaper Full-text Database, which is the most comprehensive and authoritative newspaper Full-text Database domestically. Secondly, Data Collection. Selecting the stock abbreviation of listed companies as the theme of database retrieval in specific fiscal year, we use "accurate" matching methods to manually collect newspaper reports of listed companies. Lastly, Variable Design. The natural logarithm of the number of newspaper reports is used as the proxy variable for the Print Media Monitor (PMM). Secondly, Network Media Monitor (NMM).At first, Data sources. Data comes from "Baidu news search engine" (http://news.baidu.com/), which is the maximum Chinese news search platform. It could provide Big data analysis service. Secondly, Data Collection. Using advanced search in Chinese search engine, this study selected the stock abbreviation as the key word in the year of the listed company, and searches the frequency of the keyword in the news title. Lastly, Variable Design. The natural logarithm of the number of network news reports is used as the proxy variable to Network Media Monitor (NMM).

Legal Environment: This article uses the index in different regions of "Lawyers, accountants and other market intermediary organizations service conditions", which from $<<$ China's marketization index -- a 2011 report on the relative process of marketization in all regions $>>$ as legal environment's proxy variable. The index is a positive indicator, it means the bigger the index, the better the legal environment. Since only the relevant indexes of 1997-2009 were published at the present stage, although the legal environment varies in different years, it present a relatively stable situation in each region, that is why this article presumes the marketization index of 2010-2013 is the same as 2009. In the meantime, on account of legal environment index is highly coincidence with development degree of economy, this passage add the economic development level as the control variable to the test model to weaken the bias resulting from the regression results.

3.2.3 Control variable

In order to guarantee the reliability of the results, this paper controls firm characteristics, corporate governance variables, macroeconomics variables, the main control variables are Enterprise Scale, Free Cash Flow, Debt Level, Board Size, PID, Supervisory Board Scale, Agency Cost, Economic Development Level, Year Dummy and Industry Dummy. Table 1 shows the definition of variables: 
Table 1. Definition and Measurement of Variables

\begin{tabular}{|c|c|c|c|}
\hline $\begin{array}{l}\text { Variable } \\
\text { type }\end{array}$ & Variable name & $\begin{array}{l}\text { Variable } \\
\text { symbol }\end{array}$ & Variable Econometric \\
\hline \multirow{4}{*}{$\begin{array}{l}\text { Explained } \\
\text { Variable }\end{array}$} & $\begin{array}{l}\text { Earnings } \\
\text { Management }\end{array}$ & $E M$ & $\begin{array}{l}\text { Consisting of accrual-based earnings management and real } \\
\text { earnings management }\end{array}$ \\
\hline & $\begin{array}{l}\text { Accrual-based } \\
\text { Earnings } \\
\text { Management }\end{array}$ & $A E M$ & $\begin{array}{l}\text { Absolute value of earnings management measured by cross- } \\
\text { sectional modified jones model }\end{array}$ \\
\hline & $\begin{array}{l}\text { Real Earnings } \\
\text { Management }\end{array}$ & $R E M$ & $\begin{array}{l}\text { Absolute value of real earnings management measured by real } \\
\text { earnings management aggregative model }\end{array}$ \\
\hline & Media Monitor & $M M$ & $\begin{array}{l}\text { Consisting of Print Media Monitor and Network Media } \\
\text { Monitor }\end{array}$ \\
\hline \multirow{3}{*}{$\begin{array}{l}\text { Explanator- } \\
\text { y Variable }\end{array}$} & $\begin{array}{l}\text { Print Media } \\
\text { Monitor }\end{array}$ & $P M M$ & $\begin{array}{l}\text { Natural logarithm of the number of the company's annual } \\
\text { news report in Chinese important newspaper Full- } \\
\text { text Database }\end{array}$ \\
\hline & $\begin{array}{l}\text { Network Media } \\
\text { Monitor }\end{array}$ & $N M M$ & $\begin{array}{l}\text { Natural logarithm of the number of the company's annual } \\
\text { news report in Baidu news search engine }\end{array}$ \\
\hline & $\begin{array}{l}\text { Legal } \\
\text { Environment }\end{array}$ & $L E$ & $\begin{array}{l}\text { Index of "Lawyers, accountants and other market intermediary } \\
\text { organizations service conditions" }\end{array}$ \\
\hline \multirow{10}{*}{$\begin{array}{l}\text { Control } \\
\text { Variable }\end{array}$} & Enterprise scale & Size & Natural logarithm of Gross Assets \\
\hline & Free Cash Flow & $C F$ & Free Cash Flow/Gross Assets \\
\hline & Debt Level & $D V$ & Gross Debt/Gross Assets \\
\hline & Board size & $B S$ & Natural logarithm of the number of directors \\
\hline & $\begin{array}{l}\text { Proportion of } \\
\text { Independent } \\
\text { Director }\end{array}$ & $P I D$ & The number of independent director/The number of directors \\
\hline & $\begin{array}{l}\text { Supervisory } \\
\text { Board Scale }\end{array}$ & $S B S$ & The number of number of supervisor \\
\hline & $\begin{array}{l}\text { Agency Cost } \\
\text { Economic }\end{array}$ & $A C$ & Other Receivables/Gross Assets \\
\hline & $\begin{array}{l}\text { Development } \\
\text { Level }\end{array}$ & $G D P$ & Annual GDP growth rate in each province \\
\hline & Year Dummy & Year & $\begin{array}{l}\text { Controlling annual macroeconomic impact, setting } 4 \\
\text { Year dummy variable }\end{array}$ \\
\hline & Industry Dummy & Ind & $\begin{array}{l}\text { Control the impact of industry factors, setting } 11 \text { Industry } \\
\text { dummy variable }\end{array}$ \\
\hline
\end{tabular}

\subsection{Model Specification}

To test the hypothesis $\mathrm{H} 1$ and find the mechanism to earnings management from media monitor, we construct following multiple linear regression model:

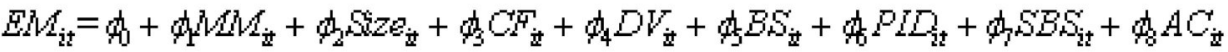

$$
\begin{aligned}
& +\phi_{g} G D P_{\text {it }}+\phi_{10} Y e a r_{\text {ji }}+\phi_{11} I m d_{\text {it }}+\tau_{\text {it }}
\end{aligned}
$$

Where, EMit represents the degree of earnings management in period t, consisting of accrual-based earnings management AEMit and real earnings management REMit ; MMit represents the degree of media monitor in period $t$, consisting of print media monitor PMMit and network media monitor NMMit.

To test the hypothesis $\mathrm{H} 2$ and searching the empirical evidence of the change in earnings management strategy of listed company monitored by media, we construct following multiple linear regression model:

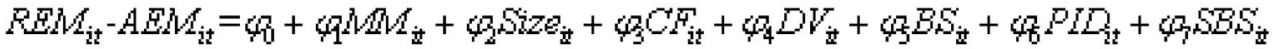

$$
\begin{aligned}
& +\varphi_{B} A C_{i t}+\varphi_{j} G D P_{i t}+\varphi_{10} Y e a r_{i t}+\varphi_{11} h d_{i t}+\theta_{i t}
\end{aligned}
$$

Where, REMit-AEMit represents the balance between real earnings management and accrual-based earnings management. The larger the difference, the more likely that listed companies will prefer to use real earnings management.

To test the hypothesis $\mathrm{H} 3$ and investigate the substitution effect or complementary effect of media supervision and rule of law environment in earnings management of listed companies, we construct following multiple linear regression model: 


$$
\begin{aligned}
E M_{i t}= & \gamma_{0}+\gamma_{1} M M M_{\text {it }}+\gamma_{2} M M_{i t} \times L E_{i t}+\gamma_{3} L E_{\text {it }}+\gamma_{4} S z e_{\text {it }}+\gamma_{5} C F_{\text {it }}+\gamma_{6} D V_{i t}+\gamma_{7} B S_{\text {it }}+\gamma_{8} P I D_{\text {it }} \\
& +\gamma_{9} S B S_{\text {it }}+\gamma_{10} A C_{\text {it }}+\gamma_{11} G D P_{\text {it }}+\gamma_{12} Y e a r_{\text {it }}+\gamma_{\mathrm{Z}} M d_{\text {it }}+v_{\text {it }}
\end{aligned}
$$

LEit represents the local legal environment in t period; MMit $\times$ LEit represents a cross-term for media monitor and the legal environment.

\section{Empirical Results and Analysis}

\subsection{Descriptive statistics}

According to statistical results provided by table 2, the median of the print media monitor PMM is 1.688 . This shows that our listed companies have been reported by the print media on average five times; the median of the network media monitor NMM is 5.642, and this shows that our listed companies have been reported by the network media on average five times. After comparison can be found, the number of the network media report times greater than the number of the print media report times, it is mainly due to people's reading style in gradual change at present, and the network media has become an important vehicle for the investors to get the listed company information. In combination with the minimum value and maximum value of media monitor variables, there are also great differences in the number of reports of media to listed companies. Some listed companies have not even been reported by the media.

Table 2. Results of Descriptive Statistics of Variables

\begin{tabular}{lllllllll}
\hline Variable & Sample Size & Mean & Median & Standard Deviation & Eccentric State & Kurtosis & Minimum & Maximum \\
\hline AEM & 6261 & 0.106 & 0.066 & 0.127 & 2.499 & 6.762 & 0.000 & 0.678 \\
REM & 6261 & 0.289 & 0.171 & 0.346 & 2.472 & 6.912 & 0.000 & 1.884 \\
PMM & 6261 & 1.668 & 1.609 & 1.344 & 0.398 & -0.530 & 0.000 & 6.415 \\
NMM & 6261 & 5.642 & 5.951 & 2.169 & 0.002 & 3.302 & 0.000 & 17.315 \\
LE & 6261 & 6.311 & 6.460 & 1.760 & -2.635 & 25.250 & -12.270 & 10.000 \\
Size & 6261 & 21.173 & 21.141 & 1.674 & 0.041 & 1.188 & 13.879 & 28.282 \\
CF & 6261 & 0.061 & 0.055 & 0.100 & 0.326 & 1.186 & -0.216 & 0.376 \\
DV & 6261 & 0.509 & 0.527 & 0.202 & -0.394 & -0.304 & 0.012 & 0.912 \\
BS & 6261 & 2.504 & 2.485 & 0.314 & -0.111 & 0.539 & 0.693 & 3.638 \\
PID & 6261 & 0.344 & 0.333 & 0.095 & 0.487 & 0.525 & 0.053 & 0.667 \\
SBS & 6261 & 1.582 & 1.609 & 0.470 & -0.353 & 0.471 & 0.000 & 2.944 \\
AC & 6261 & 0.017 & 0.010 & 0.019 & 1.667 & 2.393 & 0.000 & 0.097 \\
GDP & 6261 & 0.173 & 0.182 & 0.053 & -0.455 & 0.005 & 0.006 & 0.323 \\
\hline
\end{tabular}

\subsection{Correlation Analysis}

We conduct Pearson correlation test. The results in table 3 show that the variables involved in this paper do not have multiple collinear problems. Though the correlation coefficient of the print media monitor PMM and the network media monitor NMM is 0.591 , these two variables do not appear at the same time in the regression model. So the common linear problem has little impact on the model estimation. In order to ensure the robustness of the estimation conclusion, the variance expansion factor test was carried out in the following regression, and the test results supported the above statement.

\begin{tabular}{|c|c|c|c|c|c|c|c|c|c|c|c|c|c|}
\hline Variable & $A E M$ & REM & $P M M$ & $N M M$ & $L E$ & Size & $C F$ & $D V$ & $B S$ & $P I D$ & $S B S$ & $A C$ & $G D P$ \\
\hline$A E M$ & 1.000 & & & & & & & & & & & & \\
\hline REM & $0.486^{* * *}$ & 1.000 & & & & & & & & & & & \\
\hline$P M M$ & $-0.117^{* * *}$ & $-0.085^{* * *}$ & 1.000 & & & & & & & & & & \\
\hline$N M M$ & $-0.093^{* * *}$ & $-0.075^{* * *}$ & $0.591^{* * *}$ & 1.000 & & & & & & & & & \\
\hline$L E$ & $-0.115^{* * *}$ & $-0.022^{*}$ & $-0.025^{* *}$ & $-0.035^{* * *}$ & 1.000 & & & & & & & & \\
\hline Size & $-0.194^{* * *}$ & $-0.228^{* * *}$ & 0.017 & $0.030^{* *}$ & $-0.053^{* * *}$ & 1.000 & & & & & & & \\
\hline$C F$ & $-0.026^{* *}$ & $0.068^{* * *}$ & $-0.023^{*}$ & $-0.029^{* *}$ & 0.010 & $-0.125^{* * *}$ & 1.000 & & & & & & \\
\hline$D V$ & -0.001 & 0.008 & $0.071^{* * *}$ & $0.078^{* * *}$ & 0.006 & $-0.026^{* *}$ & 0.003 & 1.000 & & & & & \\
\hline$B S$ & 0.004 & $-0.023^{*}$ & $0.054^{* * *}$ & $0.049^{* * *}$ & 0.001 & 0.002 & -0.003 & $0.066^{* * *}$ & 1.000 & & & & \\
\hline PID & $-0.085^{* * *}$ & $-0.047^{* * *}$ & $0.027^{* * *}$ & $0.026^{* *}$ & -0.006 & 0.003 & 0.010 & $-0.023^{*}$ & $-0.311^{* * *}$ & 1.000 & & & \\
\hline$S B S$ & -0.020 & -0.020 & $0.023^{*}$ & $0.021^{*}$ & 0.006 & 0.004 & 0.000 & $0.050^{* * *}$ & $0.399^{* * *}$ & $-0.131^{* * *}$ & 1.000 & & \\
\hline$A C$ & $0.123^{* * *}$ & $0.079^{* * *}$ & $-0.051^{* * *}$ & $-0.044^{* * *}$ & $-0.022^{*}$ & $-0.021^{*}$ & 0.010 & $0.088^{* * *}$ & $-0.028^{* *}$ & $0.022^{*}$ & $-0.024^{*}$ & 1.000 & \\
\hline$G D P$ & $0.046^{* * *}$ & $0.088^{* * *}$ & $0.029^{* *}$ & $-0.050^{* * *}$ & $0.094^{* * *}$ & $-0.057^{* * *}$ & $-0.084^{* * *}$ & 0.020 & -0.002 & -0.017 & $0.030^{* *}$ & 0.019 & 1.000 \\
\hline
\end{tabular}

Table 3. Results of Pearson Correlation Test

4.3 Research on the governance effect of Media Monitor on Earnings Management of listed company

Table 4 shows the empirical results of governance effect on the earnings management of listed companies by media monitor. The first is the regression results of the print media monitor PMM and accrual-based earnings management AEM. The second is the regression result of the network media monitor NMM and accrual-based earnings management AEM. The third is the regression result of the print media monitoring PMM and real earnings management REM. The fourth listed the regression results of network media monitor NMM and real earnings management REM. On the one hand, the governance effect of the accrual-based earnings management of listed 
companies by the media monitor. From the table, it can be found that the print media monitor PMM, the network media monitor NMM and the accrual-based earnings management AEM are all significantly negatively correlated at the $1 \%$ level. The regression coefficients are -0.009 and -0.005 respectively. This shows that media monitor can effectively restrain the accrual-based earnings management of listed companies. On the other hand, the governance effect on the real earnings management of listed companies by the media monitor. It can be seen from the table that the print media monitor PMM, the network media monitor NMM and the real earnings management REM are significantly negatively correlated with the $1 \%$ level. The regression coefficients are -0.019 and- 0.009 respectively. The media monitor can effectively reduce the degree of the real earnings management of listed companies. Overall, the media monitor can significantly reduce the accrual-based earnings management and real earnings management of listed companies. The media plays a huge role in earnings management governance, and the test results prove the research hypothesis $\mathrm{H} 1$ in this paper.

Table 4. Test Results of Governance Effect of Media Monitoring on Earnings Management

\begin{tabular}{|c|c|c|c|c|}
\hline \multirow{3}{*}{ Variable } & \multicolumn{2}{|c|}{ Dependent Variable: AEM } & \multicolumn{2}{|c|}{ Dependent Variable: REM } \\
\hline & Independent & Independent & Independent & Independent \\
\hline & Variable: PMM & Variable: NMM & Variable: PMM & Variable: NMM \\
\hline \multirow{2}{*}{ Intercept Term } & $0.455^{* * *}$ & $0.475^{* * *}$ & $1.319^{* * *}$ & $1.357^{* * *}$ \\
\hline & $(15.661)$ & $(16.205)$ & $(16.610)$ & $(16.945)$ \\
\hline \multirow{2}{*}{ PMM } & $-0.009^{* * *}$ & & $-0.019^{* * *}$ & \\
\hline & $(-8.050)$ & & $(-5.855)$ & \\
\hline \multirow{2}{*}{ NMM } & & $-0.005^{* * *}$ & & $-0.009^{* * *}$ \\
\hline & & $(-6.315)$ & & $(-4.380)$ \\
\hline \multirow{2}{*}{ Size } & $-0.014^{* * *}$ & $-0.015^{* * *}$ & $-0.044^{* * *}$ & $-0.044^{* * *}$ \\
\hline & $(-15.422)$ & $(-15.449)$ & $(-17.218)$ & $(-17.241)$ \\
\hline \multirow{2}{*}{$\mathrm{CF}$} & $-0.067^{* * *}$ & $-0.065^{* * *}$ & $0.165^{* * *}$ & $0.169^{* * *}$ \\
\hline & $(-4.205)$ & $(-4.078)$ & $(3.821)$ & $(3.905)$ \\
\hline \multirow{2}{*}{ DV } & -0.007 & -0.009 & 0.003 & -0.001 \\
\hline & $(-0.932)$ & $(-1.183)$ & $(0.153)$ & $(-0.048)$ \\
\hline \multirow{2}{*}{$\mathrm{BS}$} & -0.001 & -0.002 & $-0.028^{*}$ & $-0.030^{*}$ \\
\hline & $(-0.187)$ & $(-0.301)$ & $(-1.847)$ & $(-1.940)$ \\
\hline \multirow{2}{*}{ PID } & $-0.110^{* * *}$ & $-0.112^{* * *}$ & $-0.179^{* * *}$ & $-0.184^{* * *}$ \\
\hline & $(-6.379)$ & $(-6.492)$ & $(-3.821)$ & $(-3.916)$ \\
\hline \multirow{2}{*}{ SBS } & -0.006 & -0.006 & -0.010 & -0.010 \\
\hline & $(-1.619)$ & $(-1.583)$ & $(-1.030)$ & $(-1.005)$ \\
\hline \multirow{2}{*}{$\mathrm{AC}$} & $0.811^{* * *}$ & $0.835^{* * *}$ & $1.340^{* * *}$ & $1.388^{* * *}$ \\
\hline & $(9.496)$ & $(9.763)$ & $(5.743)$ & $(5.946)$ \\
\hline \multirow{2}{*}{ GDP } & 0.045 & 0.043 & $0.325^{* * *}$ & $0.323^{* * *}$ \\
\hline & $(1.011)$ & $(0.965)$ & $(2.660)$ & $(2.633)$ \\
\hline Year/Ind & Control & Control & Control & Control \\
\hline $\mathrm{F}$ & $22.870^{* * *}$ & $21.750^{* * *}$ & $22.370^{* * *}$ & $21.690^{* * *}$ \\
\hline adjustive R2 & 0.077 & 0.074 & 0.076 & 0.074 \\
\hline Sample Size & 6261 & 6261 & 6261 & 6261 \\
\hline
\end{tabular}

Notes: ${ }^{* * *},{ }^{* *},{ }^{*}$ and ${ }^{* *}$ are significant at $1 \%, 5 \%$ and $10 \%$ respectively. The value of $t$ in brackets

4.4 Research on the effect on the selection of earnings management strategies of listed companies by media monitor

Table 5 shows the empirical results of the selection on earnings management strategies of listed companies by media monitor. The first listed the regression results of the print media monitor PMM and the two earnings management balances REM-AEM, and the second listed the regression results of the network media monitor NMM and the two surplus management differences REM-AEM. From table 5, it can be found that the print media monitor PMM is significantly negatively correlated with the difference between the two earnings management balances REM-AEM, at the $1 \%$ level. The regression coefficient is -0.030 ; the network media monitor NMM has a significant negative correlation with the difference between the two earnings management balances REM-AEM at $5 \%$ level. The regression coefficient is -0.004 . It can be explained that, with the continuous strengthening of the supervision of print media and the supervision of network media, the difference between the two earnings management balances is getting bigger and bigger. Under the pressure of media supervision, listed companies prefer to use real earnings management and reduce the use of accrual-based earnings management, confirming the research hypothesis $\mathrm{H} 2$ in this paper. With the continuous strengthening of media supervision, investors have more opportunity to understand the true financial information of listed companies, because accrual-based earnings 
management is more likely to be found, this will force reduces accrual-based earnings management of listed companies. At the same time, as a new way of earnings management, real earnings management has more strong concealment, and it is difficult to be perceived by investors and regulators. So listed companies will be a greater use of real earnings management means to achieve the purpose of regulating earnings. Cohen et al. (2010) found a partial substitution between accrual-based earnings management and real earnings management. From outside the system mechanism, this study found that the media monitor in listed companies' earnings management strategy play the important role. With important practical significance and theoretical value. It is helpful to understand the theoretical and practical circles of earnings management strategy shift.

Table 5. Test Results of the Impact of Media Monitoring on Earnings Management Strategy Selection

\begin{tabular}{|c|c|c|}
\hline \multirow{2}{*}{ Variable } & \multicolumn{2}{|c|}{ Dependent Variable: REM-AEM } \\
\hline & Independent Variable: PMM & Independent Variable: NMM \\
\hline \multirow{2}{*}{ Intercept Term } & $0.864^{* * *}$ & $0.882^{* * *}$ \\
\hline & $(12.137)$ & $(12.293)$ \\
\hline \multirow{2}{*}{ PMM } & $-0.030^{* * *}$ & \\
\hline & $(-3.245)$ & \\
\hline \multirow{2}{*}{ NMM } & & $-0.004^{* *}$ \\
\hline & & $(-2.308)$ \\
\hline \multirow{2}{*}{ Size } & $-0.030^{* * *}$ & $-0.030^{* * *}$ \\
\hline & $(-12.912)$ & $(-12.932)$ \\
\hline \multirow{2}{*}{$\mathrm{CF}$} & $0.232^{* * *}$ & $0.134^{* * *}$ \\
\hline & $(5.979)$ & $(6.027)$ \\
\hline \multirow{2}{*}{ DV } & 0.011 & 0.008 \\
\hline & $(0.551)$ & $(0.429)$ \\
\hline \multirow{2}{*}{ BS } & $-0.027^{* *}$ & $-0.028^{* *}$ \\
\hline & $(-1.984)$ & $(-2.043)$ \\
\hline \multirow{2}{*}{ PID } & $-0.070^{*}$ & $-0.072^{*}$ \\
\hline & $(-1.659)$ & $(-1.718)$ \\
\hline \multirow{2}{*}{ SBS } & -0.004 & -0.004 \\
\hline & $(-0.489)$ & $(-0.474)$ \\
\hline \multirow{2}{*}{$\mathrm{AC}$} & $0.529^{* *}$ & $0.553^{* * *}$ \\
\hline & $(2.530)$ & $(2.647)$ \\
\hline \multirow{2}{*}{ GDP } & $0.280^{* *}$ & $0.279^{* *}$ \\
\hline & $(2.554)$ & $(2.545)$ \\
\hline Year/Ind & Control & Control \\
\hline $\mathrm{F}$ & $25.850^{* * *}$ & $13.330^{* * *}$ \\
\hline adjustive R2 & 0.093 & 0.045 \\
\hline Sample Size & 6261 & 6261 \\
\hline
\end{tabular}

4.5 Research on the governance effect of Media Monitor and Legal Environment on Earnings Management of listed company

Table 6 shows the empirical results of governance effect on the earnings management and legal environment of listed companies by media monitor. First, the results of the governance effect of the print media monitor PMM and the legal environment LE corresponding to the accrual-based earnings management AEM, The second is the research result of the governance effect of the network media monitor NMM and the legal environment LE corresponding to the accrual-based earnings management AEM, The third is the research result of the governance effect of the print media monitor PMM and the legal environment LE on the real earnings management REM, Fourthly, the study results of the governance effect of the network media monitor NMM and the legal environment LE on the real earnings management REM. On the one hand, the governance effect of the accrual-based earnings management and the legal environment of listed companies by the media monitor. From table 6 , it can be seen that the print media monitor PMM, the network media monitor NMM and the accrual-based earnings management AEM are all significantly negatively correlated at the $1 \%$ level. The regression coefficients are -0.027 and -0.025 respectively. This is consistent with the previous findings and further confirms the reliability of this study. The cross-term of the print media monitor PMM and the rule of legal environment (PMM x LE), the network media monitor NMM and the rule of legal environment (NMM x LE) and the accrual-based earnings management AEM are significantly positively correlated at the $1 \%$ level. The regression coefficient is 0.003 . This shows that both print and network media monitor in poor legal environment has a strong constraint function with the accrual-based earnings management of listed companies, and this constraint function decreased significantly in good legal environment. On the other hand, the governance effect on the real earnings management of listed companies by 
the media monitor and legal environment. The print media monitor PMM, the network media monitor NMM and the real earnings management REM are significantly negatively correlated at the $1 \%$ level, The cross-term of the media monitor MM and the rule of legal environment (MM x LE)and the real earnings management (REM) are significantly positively correlated at the $1 \%$ level. This indicates that the media monitor in poor legal environment is more restrictive to the real earnings management of listed companies than the good legal environment. Overall, the media monitor and the legal environment in earnings management governance exist substitution effect significantly. When the mandatory action mechanism cannot effectively play the role of the constraints of the listed company's earnings management in legal aspect, the media monitor as an alternative action mechanism derived by the market can make up for the defect of inadequate legal protection, confirming the research hypothesis $\mathrm{H} 3$ in this paper. China is in a transition development period, and legal construction has certain regional differences. Legal environment in part of the backward areas cannot constraint the earnings management behavior of listed company effectively. The media monitor as a substitute for the market governance mechanism can play a role of earnings management governance to make up the defects of caused by the lack of legal protection. This enlightens us that under the background of China's specific system, weak legal environment did not rein in the role of the media management, the media can highlight more important role in the listed company earnings management governance in the weak legal environment.

Table 6 Test Results of Governance Effect of Media Monitoring and Legal Environment on Earnings Management

\begin{tabular}{|c|c|c|c|c|}
\hline \multirow{3}{*}{ Variable } & \multicolumn{2}{|c|}{ Dependent Variable: AEM } & \multicolumn{2}{|c|}{ Dependent Variable: REM } \\
\hline & Independent & Independent & Independent & Independent \\
\hline & Variable: PMM & Variable: NMM & Variable: PMM & Variable: NMM \\
\hline \multirow{2}{*}{ Intercept Term } & $0.545^{* * *}$ & $0.631^{* * *}$ & $1.393^{* * *}$ & $1.448^{* * *}$ \\
\hline & $(18.061)$ & $(20.103)$ & $(16.740)$ & $(16.641)$ \\
\hline \multirow{2}{*}{ PMM } & $-0.027^{* * *}$ & & $-0.063^{* * *}$ & \\
\hline & $(-6.209)$ & & $(-5.316)$ & \\
\hline \multirow{2}{*}{$\mathrm{PMM} \times \mathrm{LE}$} & $0.003^{* * *}$ & & $0.007^{* * *}$ & \\
\hline & $(4.091)$ & & $(3.880)$ & \\
\hline \multirow{2}{*}{ NMM } & & $-0.025^{* * *}$ & & $-0.028^{* * *}$ \\
\hline & & $(-10.346)$ & & $(-4.315)$ \\
\hline \multirow{2}{*}{$\mathrm{NMM} \times \mathrm{LE}$} & & $0.003^{* * *}$ & & $0.003^{* * *}$ \\
\hline & & $(8.698)$ & & $(3.109)$ \\
\hline \multirow{2}{*}{ LE } & $-0.014^{* * *}$ & $-0.025^{* * *}$ & $-0.011^{* * *}$ & $-0.014^{* * *}$ \\
\hline & $(-9.925)$ & $(-12.592)$ & $(-2.911)$ & $(-2.680)$ \\
\hline \multirow{2}{*}{ Size } & $-0.015^{* * *}$ & $-0.015^{* * *}$ & $-0.044^{* * *}$ & $-0.044^{* * *}$ \\
\hline & $(-15.990)$ & $(-15.872)$ & $(-17.251)$ & $(-17.164)$ \\
\hline \multirow{2}{*}{$\mathrm{CF}$} & $-0.067^{* * *}$ & $-0.066^{* * *}$ & $0.160^{* * *}$ & $0.167^{* * *}$ \\
\hline & $(-4.285)$ & $(-4.207)$ & $(3.711)$ & $(3.851)$ \\
\hline \multirow{2}{*}{ DV } & -0.008 & -0.011 & 0.002 & -0.003 \\
\hline & $(-0.997)$ & $(-1.372)$ & $(0.084)$ & $(-0.115)$ \\
\hline \multirow{2}{*}{ BS } & -0.001 & -0.001 & $-0.028^{*}$ & $-0.029^{*}$ \\
\hline & $(-0.236)$ & $(-0.263)$ & $(-1.845)$ & $(-1.907)$ \\
\hline \multirow{2}{*}{ PID } & $-0.110^{* * *}$ & $-0.113^{* * *}$ & $-0.178^{* * *}$ & $-0.184^{* * *}$ \\
\hline & $(-6.482)$ & $(-6.665)$ & $(-3.791)$ & $(-3.918)$ \\
\hline \multirow{2}{*}{ SBS } & $-0.006^{*}$ & $-0.006^{*}$ & -0.011 & -0.011 \\
\hline & $(-1.651)$ & $(-1.771)$ & $(-1.076)$ & $(-1.076)$ \\
\hline \multirow{2}{*}{$\mathrm{AC}$} & $0.785^{* * *}$ & $0.785^{* * *}$ & $1.321^{* * *}$ & $1.358^{* * *}$ \\
\hline & $(9.280)$ & $(9.313)$ & $(5.665)$ & $(5.814)$ \\
\hline \multirow{2}{*}{ GDP } & $0.090^{* *}$ & $0.076^{*}$ & $0.317^{* * *}$ & $0.306^{* *}$ \\
\hline & $(2.017)$ & (1.704) & $(2.585)$ & $(2.487)$ \\
\hline Year/Ind & Control & Control & Control & Control \\
\hline $\mathrm{F}$ & $26.670^{* * *}$ & $28.060^{* * *}$ & $21.270^{* * *}$ & $20.420^{* * *}$ \\
\hline adjustive R2 & 0.096 & 0.101 & 0.078 & 0.075 \\
\hline Sample Size & 6261 & 6261 & 6261 & 6261 \\
\hline
\end{tabular}

\section{6 sensitivity analysis}

The sensitivity test of this study is mainly carried out in the following two aspects: On the one hand, eliminate truncation problem in the sample. Since there may be some truncation problems in the data that relates to the degree of media supervision selected in this paper, in order to avoid noise adversely impacting research conclusions, 
This study excludes the sample that the degree of media supervision is 0 , only use samples the degree of media supervision is greater than 0 for empirical testing. Through the above-mentioned disposing, the empirical results and the previous text have no substantive differences. On the other hand, replace the proxy variable of accrualbased earnings management. To ensure the robustness of the conclusions, this paper analyzes the earnings management of Jones model. The findings are consistent with the above.

\section{Re-examination of Weakening Endogenous Problem}

\subsection{Consider re-examination of sample self-selection}

It has been pointed out that interference in endogenous problems can't be ignored in the media governance related researches. By the influence of profit motives, the media will selectively report the news, which makes the media reports may be biased. Therefore, the sample is not randomly distributed, but self-selection distribution. In this paper, Heckman two-stage model is proposed to weaken the endogenous problems existed in the study, and further test the robustness of the conclusion. The study aslo constructs the media monitoring determinants model, utilize Probit regression to estimate the probability of media supervision as well as calculate the inverse Mills ratio IMR.

$$
\begin{aligned}
& D M M_{\text {it }}=\eta_{0}+\eta_{1} S z e_{i t}+\eta_{2} V a l l e_{i t}+\eta_{3} C F_{\text {it }}+\eta_{4} D V_{i t}+\eta_{5} R O A_{i t}+\eta_{6} G r_{\text {it }}+\eta_{7} B S_{i t}+\eta_{8} P D D_{\text {it }} \\
& +\eta_{g} S B S_{\text {it }}+\eta_{10} H_{i t}+\eta_{11} Y e a r_{\text {it }}+\eta_{12} I n d_{\text {it }}+\sigma_{\text {it }}
\end{aligned}
$$

Where, DMMi represents the dual virtual variable of the media monitor in period $t$, When the media monitor $\mathrm{MM}$ is greater than the median, the value is 1.000 ; otherwise it is 0.000 ; Valueit represents the corporate value in period $t$, defined as the sum of stock price and net debt; ROAit represents return on total asset in period t; Groit represents the growth of enterprise in period $t$, defined as growth rate of operating revenue; Hit represents ownership concentration in period $t$, defined as the square of share ratio hold by largest shareholder.

The inverse Mills ratio IMR was added to the model (7), model (8) and model (9) as control variables, and model (11), model (12) and model (13) were reconstructed to make Regression analysis.

$$
\begin{aligned}
& E M_{\text {it }}=\lambda_{0}+\lambda_{1} M M_{\text {it }}+\lambda_{2} S z e_{i t}+\lambda_{5} C F_{\text {it }}+\lambda_{4} D V_{\text {it }}+\lambda_{5} B S_{\text {it }}+\lambda_{6} P L D_{\text {it }}+\lambda_{7} S B S_{\text {it }}+\lambda_{8} A C_{\text {it }} \\
& +\lambda_{9} C D P_{\text {it }}+\lambda_{10} I M R_{\text {it }}+\lambda_{11} Y e a r_{i t}+\lambda_{22} I n d_{i t}+\xi_{\text {it }} \\
& R E M_{i t}-A E M_{\text {it }}=\mu_{0}+\mu_{1} M M_{\text {it }}+\mu_{2} S i z e_{\text {it }}+\mu_{3} C F_{\text {it }}+\mu_{4} D V_{\text {it }}+\mu_{5} B S_{\text {it }}+\mu_{6} P I D_{t}+\mu_{7} S B S_{\text {it }} \\
& +\mu_{g} A C_{\text {it }}+\mu_{9} G D P_{\text {it }}+\mu_{10} D M R_{\text {it }}+\mu_{11} Y e a r_{i t}+\mu_{12} I n d_{\mathrm{it}}+a_{\mathrm{it}} \\
& E M_{i t}=\xi_{0}+\xi_{1} M M_{i t}+\xi_{2} M M M_{i t} \times L E_{i t}+\xi_{3} L E_{i t}+\xi_{4} S z e_{i t}+\xi_{5} C F_{\text {it }}+\xi_{6} D V_{\text {it }}+\xi_{7} B S_{i t}+\xi_{8} P I D_{i t} \\
& +\xi_{9} S B S_{\text {it }}+\xi_{10} A C_{\text {it }}+\xi_{11} G D P_{\text {it }}+\xi_{12} D M P_{\text {it }}+\xi_{\mathrm{D}} Y e a r_{\text {it }}+\xi_{14} I n d_{\text {it }}+t_{\text {it }}
\end{aligned}
$$

Table 7 is the regression result of Heckman phase 2 of model (11), model (12) and model (13). Due to space limitations, corresponding contents of the analysis section of table 4, table 5 and table 6 can be shown in the table without giving unnecessary details. By comparison, the results of this paper have not changed after controlling the selection problem, which further illustrates the robustness of the study conclusions. In relevant regression of print media monitor, regression coefficients of the inverse Mills ratio IMR are not significant in the model, which suggest that newspapers as the medium of media management does not exist in the research sample selection bias. In regression of the network media monitor, however, the fourth inverse mills ratio of IMR regression coefficient in column $\mathrm{A}$ and column $\mathrm{C}$ is significant at the 5\% confidence level. This shows that the network media in news reports appears the selection problems. In recent years, the network media report with bias or false occurs frequently, and it is seriously affected the credibility of network media. The Publicity Department of the Communist Party of China, State Administration of Press, Publication, Radio, Film and Television repeatedly post definite requirement to standardize news reports more real, objective and accurate. The network media should strengthen the industry self-discipline, and be abided by the professional ethics. They also ought to enhance their independence and fairness, and refuse to make false or biased reports so as to effectively maintain the social credibility of media reports. 
Table 7. Regression Results of Heckman Two-step Estimation Control Sample Selection

\begin{tabular}{|c|c|c|c|c|}
\hline \multicolumn{5}{|c|}{ Column A: Regression Results of Heckman Two-step in model (11) } \\
\hline & \multicolumn{2}{|c|}{ Dependent Variable: AEM } & \multicolumn{2}{|c|}{ Dependent Variable: REM } \\
\hline Variable & Independent & Independent & Independent & Independent \\
\hline PMM & $\begin{array}{l}\text { Variable: PMM } \\
-0.008^{* * *} \\
(-3.163)\end{array}$ & Variable: NMM & $\begin{array}{c}\text { Variable: PMM } \\
-0.030^{* * *} \\
(-4.111)\end{array}$ & Variable: NMM \\
\hline NMM & & $\begin{array}{l}-0.003^{* *} \\
(-1.961)\end{array}$ & & $\begin{array}{c}-0.013^{* * *} \\
(-3.573)\end{array}$ \\
\hline IMR & $\begin{array}{c}0.0001 \\
(0.018)\end{array}$ & $\begin{array}{c}0.006 \\
(0.889)\end{array}$ & $\begin{array}{c}0.030 \\
(1.479)\end{array}$ & $\begin{array}{l}0.034^{* *} \\
(2.002)\end{array}$ \\
\hline Control Variable & Control & Control & Control & Control \\
\hline Wald statistics & $212.460^{* * *}$ & $218.290^{* * *}$ & $241.640^{* * *}$ & $262.710^{* * *}$ \\
\hline \multicolumn{5}{|c|}{ Column B: Regression Results of Heckman Two-step in model (12) } \\
\hline $\begin{array}{l}\text { Variable } \\
\text { PMM }\end{array}$ & \multicolumn{2}{|c|}{$\begin{array}{c}\text { Independent Variable: PMM } \\
-0.022^{* * *} \\
(-3.251)\end{array}$} & \multicolumn{2}{|c|}{ Independent Variable: NMM } \\
\hline NMM & & \multicolumn{2}{|c|}{$\begin{array}{c}-0.010^{* * *} \\
(-3.088)\end{array}$} \\
\hline IMR & \multicolumn{2}{|c|}{$\begin{array}{c}0.030 \\
(1.569)\end{array}$} & \multicolumn{2}{|c|}{$\begin{array}{c}0.029 \\
(1.611)\end{array}$} \\
\hline Control Variable & \multicolumn{2}{|c|}{ Control } & \multicolumn{2}{|c|}{ Control } \\
\hline Wald statistics & \multicolumn{2}{|c|}{$159.470^{* * *}$} & \multicolumn{2}{|c|}{$173.940^{* * *}$} \\
\hline \multicolumn{5}{|c|}{ Column C: Regression Results of Heckman Two-step in model (13) } \\
\hline & \multicolumn{2}{|c|}{ Dependent Variable: AEM } & \multicolumn{2}{|c|}{ Dependent Variable: REM } \\
\hline Variable & Independent & Independent & Independent & Independent \\
\hline PMM & $\begin{array}{l}\text { Variable: PMM } \\
-0.025^{* * *} \\
(-2.963)\end{array}$ & Variable: NMM & $\begin{array}{c}\text { Variable: PMM } \\
-0.042^{* *} \\
(-2.683)\end{array}$ & Variable: NMM \\
\hline $\mathrm{PMM} \times \mathrm{LE}$ & $\begin{array}{l}0.003^{* *} \\
(2.099)\end{array}$ & & $\begin{array}{l}0.002^{*} \\
(1.825)\end{array}$ & \\
\hline NMM & & $\begin{array}{l}-0.029^{* * *} \\
(-10.344)\end{array}$ & & $\begin{array}{l}-0.031^{* * *} \\
(-3.931)\end{array}$ \\
\hline $\mathrm{NMM} \times \mathrm{LE}$ & & $\begin{array}{c}0.004^{* * *} \\
(10.483)\end{array}$ & & $\begin{array}{l}0.003^{* *} \\
(2.575)\end{array}$ \\
\hline LE & $\begin{array}{c}-0.013^{* * *} \\
(-3.631)\end{array}$ & $\begin{array}{l}-0.033^{* * *} \\
(-13.498)\end{array}$ & $\begin{array}{l}-0.004^{* *} \\
(-2.393)\end{array}$ & $\begin{array}{l}-0.013^{*} \\
(-1.949)\end{array}$ \\
\hline IMR & $\begin{array}{c}0.00008 \\
(0.012)\end{array}$ & $\begin{array}{c}0.007 \\
(1.159)\end{array}$ & $\begin{array}{c}0.030 \\
(1.445)\end{array}$ & $\begin{array}{l}0.034^{* *} \\
(1.994)\end{array}$ \\
\hline Control Variable & Control & Control & Control & Control \\
\hline Wald statistics & $251.360^{* * *}$ & $433.740^{* * *}$ & $252.490^{* * *}$ & $270.900^{* * *}$ \\
\hline
\end{tabular}

Note: sample size is6261; In order to save space, this article has not shown the estimated results of the Probit model in the first stage and the estimated results of the relevant control variables, and the interested readers can ask for it.

\subsection{Consider the re-inspection of the sample agglomeration effect}

Based on the analysis of the samples, this paper found that samples from Beijing, Shanghai and Guangdong province accounted for 28.653\%; Samples from regions with poor rule of law, such as Tibet, Qinghai and Ningxia, accounting for only $1.964 \%$. This indicates that there may be some kind of correlation between the sample distribution and legal environment, which can interfere with the research conclusion. The method of instrumental variable is proposed to solve the sample agglomeration effect. There are three steps:

Firstly, build the model. Based on the rule of legal environment LE is interpreted as the variable, and the explanatory variable is the number of listed companies SN in each region. Construct the one-dimensional linear regression model is.

$$
L E_{u}=\kappa_{0}+\kappa_{1} S \mathrm{~N}_{u}+a_{u}
$$

Secondly, select instrumental variable. The regression residuals in model (14) are the instrumental variable $I V$ of the rule of law environment. 
Thirdly, re-regress. Replace the legal environment $L E$ in the previous model (9) with the tool variable $I V$, and construct the model (15) to re-examine.

$$
\begin{aligned}
E M_{\text {it }}= & \psi_{0}+\psi_{1} M M_{\text {it }}+\psi_{2} M M_{\text {it }} \times V_{\text {it }}+\psi_{3} I V_{i t}+\psi_{4} S z e_{\text {it }}+\psi_{5} C F_{\text {it }}+\psi_{6} D V_{\text {it }}+\psi_{7} B S_{\text {it }} \\
& +\psi_{8} P I D_{\text {it }}+\psi_{9} S B S_{\text {it }}+\psi_{10} A C_{i t}+\psi_{11} G D P_{\text {it }}+\psi_{12} Y e a r_{\text {it }}+\psi_{1} I n d_{i t}+g_{\text {it }}
\end{aligned}
$$

Table 8 shows the regression results of sample agglomeration effect eliminated. Taking the first regression results as an example, the print media monitor $P M M$ and the accrual-based earnings management $A E M$ were significantly negatively correlated at the $1 \%$ level, and the cross-term of media monitor and legal environment $\left(M M^{*} L E\right)$ and the accrual-based earnings management $A E M$ are all significantly positive at the $1 \%$ level. This shows that media monitor can play the role of earnings management governance in weak legal environment, and it is supports the research hypothesis H3. The regression results of the second column and the third column were consistent with the previous text, but the regression results of the network media and the real earnings management failed to achieve the statistical significance level. On the whole, after eliminating the sample agglomeration effect, the conclusions of this paper haven't changed.

Table 8. Regression Results of Considering the Sample's Clustering Effect

\begin{tabular}{ccccc}
\hline \multirow{2}{*}{ Variable } & \multicolumn{2}{c}{ Dependent Variable: AEM } & \multicolumn{2}{c}{ Dependent Variable: REM } \\
\cline { 2 - 5 } & $\begin{array}{c}\text { Independent } \\
\text { Variable: PMM }\end{array}$ & $\begin{array}{c}\text { Independent } \\
\text { Variable: NMM }\end{array}$ & $\begin{array}{c}\text { Independent } \\
\text { Variable: PMM }\end{array}$ & $\begin{array}{c}\text { Independent } \\
\text { Variable: NMM }\end{array}$ \\
\hline \multirow{2}{*}{ Intercept Term } & $0.462^{* * *}$ & $0.482^{* * *}$ & $1.322^{* * *}$ & $1.357^{* * *}$ \\
& $(15.840)$ & $(16.570)$ & $(16.655)$ & $(16.935)$ \\
PMM & $-0.010^{* * *}$ & & $-0.018^{* * *}$ & \\
& $(-8.287)$ & & $(-5.756)$ & $0.007^{* * *}$ \\
PMM $\times$ IV & $0.003^{* * *}$ & & $(3.872)$ & $-0.009^{* * *}$ \\
& $(4.283)$ & & & $(-4.361)$ \\
PMM & & $-0.005^{* * *}$ & & 0.001 \\
& & $(-6.600)$ & & $(0.714)$ \\
PMM $\times$ IV & & $0.001^{* *}$ & -0.005 \\
IV & & $(2.136)$ & $-0.012^{* * *}$ & $(-0.660)$ \\
Control Variable & $-0.014^{* * *}$ & $-0.009^{* * *}$ & $(-3.042)$ & Control \\
\hline F & $(-10.185)$ & $(-3.501)$ & Control & $20.040^{* * *}$ \\
adjustive R2 & Control & Control & $21.270^{* * *}$ & 0.073 \\
Sample Size & $26.930^{* * *}$ & $25.020^{* * *}$ & 0.078 & 6261 \\
\hline
\end{tabular}

\section{Research Conclusion}

In the modern society, media monitor and legal environment play an important supervisory role in the behavior of listed companies, which is deeply concerned by the academic and practical circles at home and abroad. This article takes the listed company earnings management as the entry point, and studied the governance effect of media monitor and legal environment on the earnings management of listed companies. The study found that: first, the media monitor can effective constraint of the listed company earnings management behavior, namely with the increase of the degree of media monitor, the degree of the accrual-based earnings management and real earnings management of listed companies will decrease; Second, media monitor will have an important impact on the earnings management strategy of listed companies, namely, under the pressure of media supervision, listed companies tend to use more real earnings management, and use fewer accrual-based earnings management; Third, the media monitor and legal environment in earnings management governance exist significant substitution effect. Media monitor can fill the issue of the failure of earnings management supervision due to weak legal environment. This study still has the following deficiencies to be improved: first, because of the heavy workload and the difficulty of data mining, the author failed to break down the differences in the nature of the hundreds of thousands of news reports obtained. In other words, the report is divided into positive, negative and neutral reports, which makes this study not in-depth. In the following research, the author will focus on the influence mechanism of the different nature of news reporting on the management of earnings management. Second, this paper only considering the media to release the number of news reports, but ignores the number of audiences for these news reports, such as the circulation of newspapers and magazines, the click rate of Internet news, the TV ratings, the broadcast rate and so on. In the follow-up study, the number of audience should be included in the related research on supervision and governance of listed companies. Third, in recent years, a small amount of literature has begun to focus on the phenomenon of media reporting bias, which has relaxed the assumptions of media objectivity and neutral reporting in traditional media studies. But because media bias is difficult to measuring, the impact of media 
bias on corporate governance research have not been able to make substantive progress, which is also a question worth exploring in the future.

\section{References}

Alhadab, M., Clacher, I., Keasey, K. (2015).Real and accrual earnings management and IPO failure risk. Accounting and Business Research, 45(1): 55-92.

Bartov, E., Gul, F. A., Tsui, J. S. L. (2000).Discretionary-accruals models and audit qualifications. Journal of Accounting and Economics, 30(3): 421-452.

Chi, W., Lisic, L. L., Pevzner, M. (2011).Is enhanced audit quality associated with greater real earnings management?. Accounting Horizons, 25(2): 315-335.

Cohen, D. A., Dey, A., Lys, T. Z. (2008).Real and accrual-based earnings management in the pre- and postSarbanes-Oxley periods. The Accounting Review, 83(3): 757-787.

Core, J. E., Guay, W., Larcker, D. F. (2008). The power of the pen and executive compensation. Journal of Financial Economics, 88(2): 1-25.

Defond, M., Zhang, J. (2014).A review of archival auditing research. Journal of Accounting and Economics, 58(2/3): 275-326.

Drake, M. S., Guest, N. M., Twedt, B. (2014).The media and mispricing: The role of the business press in the pricing of accounting information. The Accounting Review, 89(5): 1673-1701.

Dyck, A., Volchkova, N., Zingales, L. (2008).The corporate governance role of the media: Evidence from Russia. The Journal of Finance, 63(3): 1093-1135.

Ellman, M., Germano, F. (2009). What do the papers sell? A model of advertising and media bias. The Economic Journal, 119(537): 680-704.

Franz, D. R., Hassabelnaby, H. R., Lobo, G. J. (2014).Impact of proximity to debt covenant violation on earnings management. Review of Accounting Studies, 19(1): 473-505.

Gentzkow, M., Shapiro, J. (2006).Media bias and reputation. Journal of Political Economy, 114(2): 280-316.

Gurun, U. G., Butler, A. W. (2012).Don't believe the hype: Local media slant, local advertising, and firm value. The Journal of Finance, 67(2): 561-598.

Joe, J. R. (2003).Why Press coverage of a client influences the audit opinion. Journal of Accounting Research, 41(1): 109-133.

Miller, G. S. (2006).The press as a watchdog for accounting fraud. Journal of Accounting Research, 44(5): 10011033.

Reuter, J., Zitzewitz, E. (2006).Do ads influence editors? Advertising and bias in the financial media. Quarterly Journal of Economics, 121(1): 197-227.

Zang, A. Y. (2012).Evidence on the trade-off between real activities manipulation and accrual-based earnings management. The Accounting Review, 87(2): 675-703.

Zingales, L. (2000).In search of new foundations. The journal of Finance, 55(4): 1623-1653. 